\title{
Effect of Endometrial Sampling Procedures on Subsequent Pregnancy Rate of Cattle
}

\author{
Orlando Ramirez-Garzon ${ }^{1,2, *}$, Ricardo Soares Magalhaes ${ }^{3}$, Nana Satake ${ }^{1}{ }^{\circledR}$, Jonathan Hill ${ }^{1}$, Claudia Jimenez ${ }^{2}{ }^{\circledR}$, \\ Michael K. Holland ${ }^{1}$ and Michael McGowan ${ }^{1} \mathbb{D}$ \\ 1 School of Veterinary Science, The University of Queensland, Gatton, QLD 4343, Australia; \\ n.satake@uq.edu.au (N.S.); jonathan.hill@uq.edu.au (J.H.); mike.holland@uq.edu.au (M.K.H.); \\ m.mcgowan@uq.edu.au (M.M.) \\ 2 Facultad de Medicina Veterinaria, Universidad Nacional, Bogota 111321, Colombia; cjimeneze@unal.edu.co \\ 3 Child Health Research Centre, The University of Queensland, South Brisbane, QLD 4141, Australia; \\ r.magalhaes@uq.edu.au \\ * Correspondence: o.ramirez@uq.edu.au; Tel.: +61-424505016
}

check for updates

Citation: Ramirez-Garzon, O.; Soares Magalhaes, R.; Satake, N.; Hill, J.; Jimenez, C.; Holland, M.K.;

McGowan, M. Effect of Endometrial Sampling Procedures on Subsequent Pregnancy Rate of Cattle. Animals 2021, 11, 1683. https://doi.org/ 10.3390/ani11061683

Academic Editors: Geert Opsomer and Osvaldo Bogado Pascottini

Received: 22 April 2021

Accepted: 2 June 2021

Published: 5 June 2021

Publisher's Note: MDPI stays neutral with regard to jurisdictional claims in published maps and institutional affiliations.

Copyright: (c) 2021 by the authors. Licensee MDPI, Basel, Switzerland. This article is an open access article distributed under the terms and conditions of the Creative Commons Attribution (CC BY) license (https:/ / creativecommons.org/licenses/by/ $4.0 /)$.
Simple Summary: An important concern about conducting endometrial sampling procedures prior to breeding is the potential adverse effect on subsequent fertility of sampled cattle. Traumatic injury to the cervix and uterus and risk of introduction of infection caused by these sampling procedures may adversely affect the fertility of cattle sampled prior to breeding. To investigate this, a systematic review of publications assessing the impact of endometrial sampling on subsequent pregnancy rates was conducted. Analysis within the studies selected demonstrated that pregnancy rates were similar between sampled and non-sampled animals when procedures were performed before or around the time of breeding. Unfortunately, it was not possible to compare each sampling procedure between studies due to variation in sampling conditions (i.e., type of breed, age, reproductive status, and the sampling to breeding interval). We concluded that conducting these endometrial sampling procedures does not adversely affect subsequent fertility; therefore they could be used to more accurately identify cattle with a normal endometrium prior to conducting procedures such as embryo transfer. However, further studies with a much larger number of cattle are needed to verify the effects of endometrial sampling on pregnancy rates.

Abstract: Endometrial infections are a common cause of reproductive loss in cattle. Accurate diagnosis is important to reduce the economic losses caused by endometritis. A range of sampling procedures have been developed which enable collection of endometrial tissue or luminal cells or uterine fluid. However, as these are all invasive procedures, there is a risk that sampling around the time of breeding may adversely affect subsequent pregnancy rate. This systematic review compared the pregnancy rates (PR) of cattle which underwent uterine lavage (UL), cotton swab (CS), cytobrush (CB), cytotape (CT), or endometrial biopsy (EB) sampling procedures with those that were not sampled. Using the Preferred Reporting Items for Systematic Reviews and Meta-Analysis (PRISMA) protocol, relevant databases, including Pubmed, Web of Science, CAB Abstracts, VetMed Resource-Ruminants, and Scopus, were searched. The outcome measured was the pregnancy rate after the collection of endometrial sample(s). Seven studies, involving a total of 3693 cows, fulfilled the inclusion criteria for the systematic review and allowed the comparison of PR between sampled ( $n=1254)$ and non-sampled cows $(n=2409)$. The results of the systematic review showed that endometrial sampling procedures can be performed before breeding or shortly after insemination without adversely affecting pregnancy rates in cattle. However, further studies are needed to validate this information.

Keywords: cattle; cotton swab; endometrial biopsy; cytobrush; cytotape; uterine lavage 


\section{Introduction}

High reproductive performance in production animals such as beef and dairy cattle is vital for achieving optimal per capita return. Endometritis is a common cause of reproductive failure, especially in dairy cattle, causing increases in both calving to conception interval and culling rates $[1,2]$. Therefore, detection of endometritis in individual cows, before breeding or embryo transfer (ET), is critical.

The diagnosis of endometritis often relies on the detection of purulent or mucopurulent vulvar or cervical discharge, or palpation of enlarged, sometimes fluctuant uterine horns which lack tone. These clinical signs are usually detected by vaginoscopy $[3,4]$ transrectal palpation [5,6], and/or ultrasound [7-9]. These quick, low-cost diagnostic methods are commonly employed in routine herd health postpartum examinations. However, these methods underestimate the prevalence of subclinical endometritis [10]. Histological changes to the endometrium, such as increased presence of inflammatory cells in subclinical endometritis, can only be detected by cytology or histopathology [11]. Hence, more invasive sample collection methods such as uterine lavage (UL), intrauterine cotton swab (CS), cytobrush (CB), or cytotape (CT) sampling, and endometrial biopsy (EB) are required to confirm the diagnosis. These techniques enable the collection of epithelial and inflammatory cells (CS, UL, CB, and CT), luminal secretions (UL), and endometrial tissue (EB) that allow the inspection of deeper physiological and cellular responses not yet identifiable by routine clinical examinations. The samples obtained can be subjected to cytological examination [12,13], bacteriological culture [14], histopathological examination [15], protein analysis [16], and gene expression analysis [17] to diagnose the status of the endometrial environment.

Collectively, these methods involve a transvaginal device being inserted through the cervix (using per rectal manipulation) into the uterine body or uterine horns to collect the sample required (Figure 1). Briefly, for UL, a sterile catheter is introduced into the uterine horn and $20-50 \mathrm{~mL}$ of sterile $0.9 \%$ sodium chloride solution is infused, and then after per rectal massage of the uterine horns, the saline is aspirated [7,18]. A sterile disposable cotton swab is normally attached to the tip of a stylet of a bovine artificial insemination (AI) gun, which is then enclosed by an outer protective plastic sheath. Once in the uterine lumen, the swab is advanced through the plastic sheath and then moved backwards and forwards against the endometrium. Before removal, the swab is pulled back into the insemination gun to avoid cervical and vaginal contamination $[6,19]$. The CB [20,21] (Cytology Brush; Minitube $\mathrm{GmbH}$, Germany) is a disposable semi-rigid device, protected by a catheter that is inserted into the uterus. Within the uterus, the brush is pushed forward and rotated clockwise along the uterine wall. The CT device consists of a section of rolled paper tape attached to the tip of an AI gun stylet with the AI gun protected by a plastic sheath. Once in the uterine lumen, the rolled tape is advanced through the plastic sheath and rotated against the uterine walls [13]. For EB, the device is guided into the uterine horn, the forceps jaws are then opened and a section of the uterine wall gently pushed into the jaw and closed $[15,22]$. The size of the biopsy varies according to the device's jaw size. Recently, a new sampling device which allows the collection of endometrial cells, tissue, and uterine secretions after a single passage through the cervix has been developed [23].

The degree of endometrial injury and trauma varies with the method of sampling from likely to negligible for UL, CS, CB, and CT, to potentially moderate damage when performing EB. EB involves collection of a full thickness section of the endometrium, and in some cases a portion of the underlying myometrium (depth of tissue varies from 0.4 to $1 \mathrm{~cm})[15,24]$. In mares [25] and women [26], endometrial sampling is a routine procedure which does not apparently adversely affect the likelihood of the sampled female becoming pregnant. However, the impact of these procedures on the subsequent reproductive performance of cattle is still unclear. The objective of this study was to systematically review and summarize existing evidence related to the impact of these endometrial sampling procedures on the likelihood of sampled cattle becoming pregnant. 


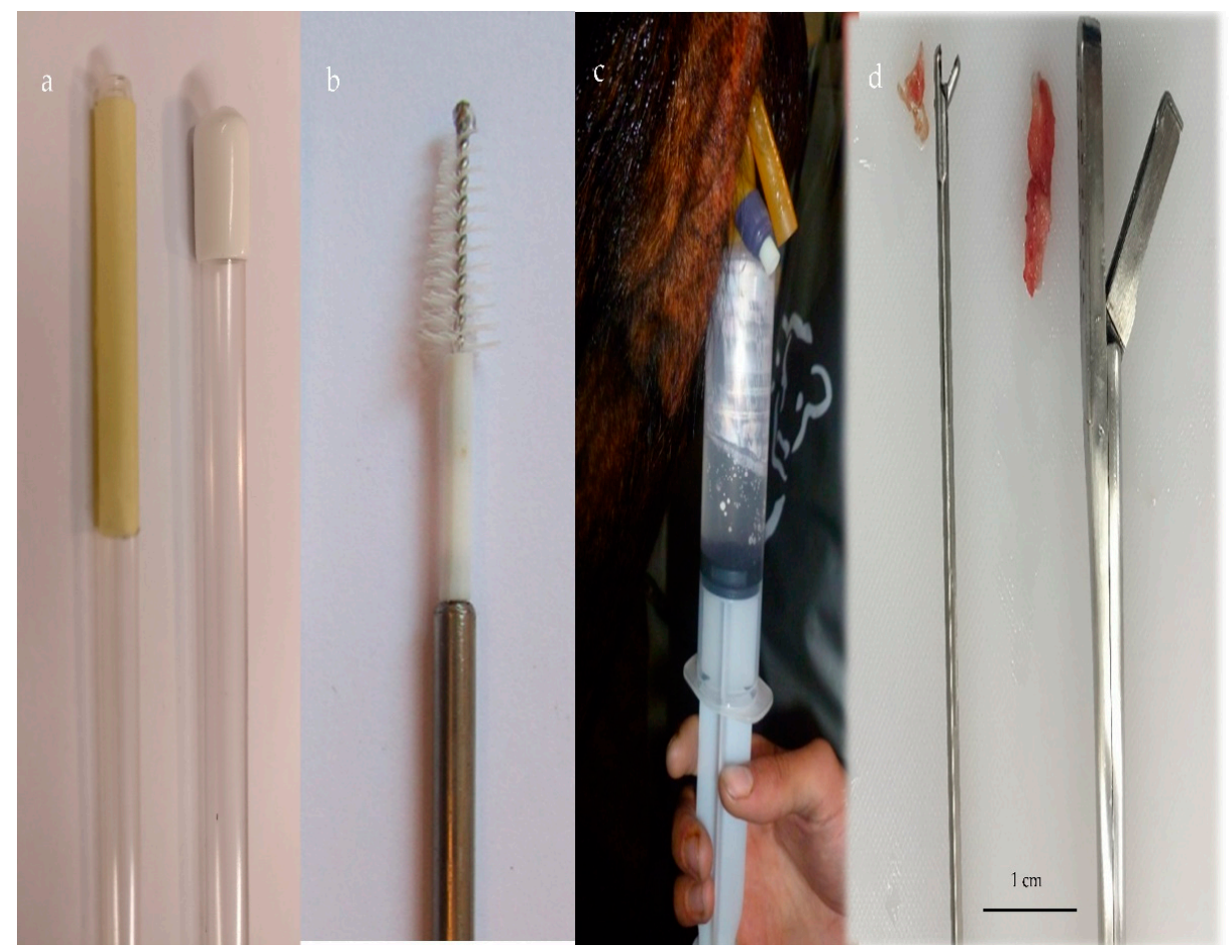

Figure 1. (a) Cytotape (Credit: Osvaldo Bogado Pascottini), (b) cytobrush, (c) uterine lavage with a saline solution using a Foley catheter, and (d) endometrial tissue with two biopsy devices.

\section{Materials and Methods}

A systematic review was conducted of studies investigating the association between pregnancy rates after collection of endometrial samples from cattle by different methods (UL, CS, CB, CT, and EB), using the Preferred Reporting Items for Systematic Reviews and Meta-Analysis (PRISMA) protocol. Online searches of literature databases were carried out in Pubmed, Web of Science, CAB Abstracts, VetMed Resource-Ruminants, and Scopus with no date limitations. A combination of the following search words was used to generate a subset of citations: cattle OR cow OR bovine OR buffalo OR bos AND uterus OR endometrial AND cytology OR cytobrush OR "cotton-swab" OR "uterine lavage" OR "uterine aspiration" OR biopsy AND fertility OR "pregnancy rate" OR "reproductive performance." Primary papers written in English, Portuguese, and Spanish were accepted from peer-reviewed journals with no date restrictions. The latest date for search was 20 February 2021.

To avoid confusion due to the large variability in terminology, an invasive endometrial sampling refers to any procedure that retrieves a sample from the uterine horns. Thus, transrectal palpation and ultrasonographic examination of the uterus, and prevaginal examination or sample collection were not considered in this review.

Eligibility criteria included (1) all types of studies, including observational, experimental, and descriptive; (2) all study settings and countries; (3) studies where an endometrial sample was collected from cattle regardless of whether they had clinical signs of endometritis or not; and (4) studies reporting the pregnancy rate after the endometrial sampling was performed. The full text was then examined and retained if (1) endometrial samples were collected either by UL, CS, CB, CT, or EB around the time of breeding or embryo transfer; (2) the pregnancy rates reported were associated only with the sampling procedure itself; and (3) the pregnancy rates of sampled animals were compared to non-sampled animals.

Duplicate citations were excluded. Titles and abstracts from non-cattle species (goat, sheep, horse, and human) studies using in vitro procedures, post-mortem material or intrauterine infusions were also excluded. Citations were also excluded if the information was published in reviews, book chapters or conference proceedings, although their refer- 
ence lists were examined for additional studies not identified by the primary search strategy. Abstracts were excluded if (1) uterine sampling procedures were used to establish the prevalence and/or threshold values for the diagnosis of clinical or subclinical endometritis; and (2) the reproductive performance was not assessed. Pregnancy rate (\%; PR) was the primary outcome measure.

All articles selected from the electronic searches and data extraction were assessed by two authors (ORG and RSM). The final decision on the studies to include in the analysis was ORG's. The following information from each study was tabulated: first author, year of publication, number of subjects (sampled and control), method of sampling, number of samplings, and pregnancy rate for sampled and control cattle.

\section{Results}

The studies were selected and reported according to the PRISMA 2009 guidelines (Figure 2). A total of 729 studies were identified, and 235 duplicate references were discarded. After reading the title and applying the exclusion criteria, 223 studies were excluded. A total of 271 citations were screened and 215 were excluded after reading the abstracts. Fifty-six publications were retrieved for a full text appraisal, with 49 subsequently excluded because they did not meet the predefined inclusion criteria (Table 1).

Records identified through database searching $(20 / 02 / 2021)$

$\begin{array}{ll}\text {-Scopus } & 21 \\ \text {-Web of Science } & 247 \\ \text {-Pubmed } & 261 \\ \text {-CABI VetMed Resource } & 200\end{array}$

TOTAL Records identified through 729

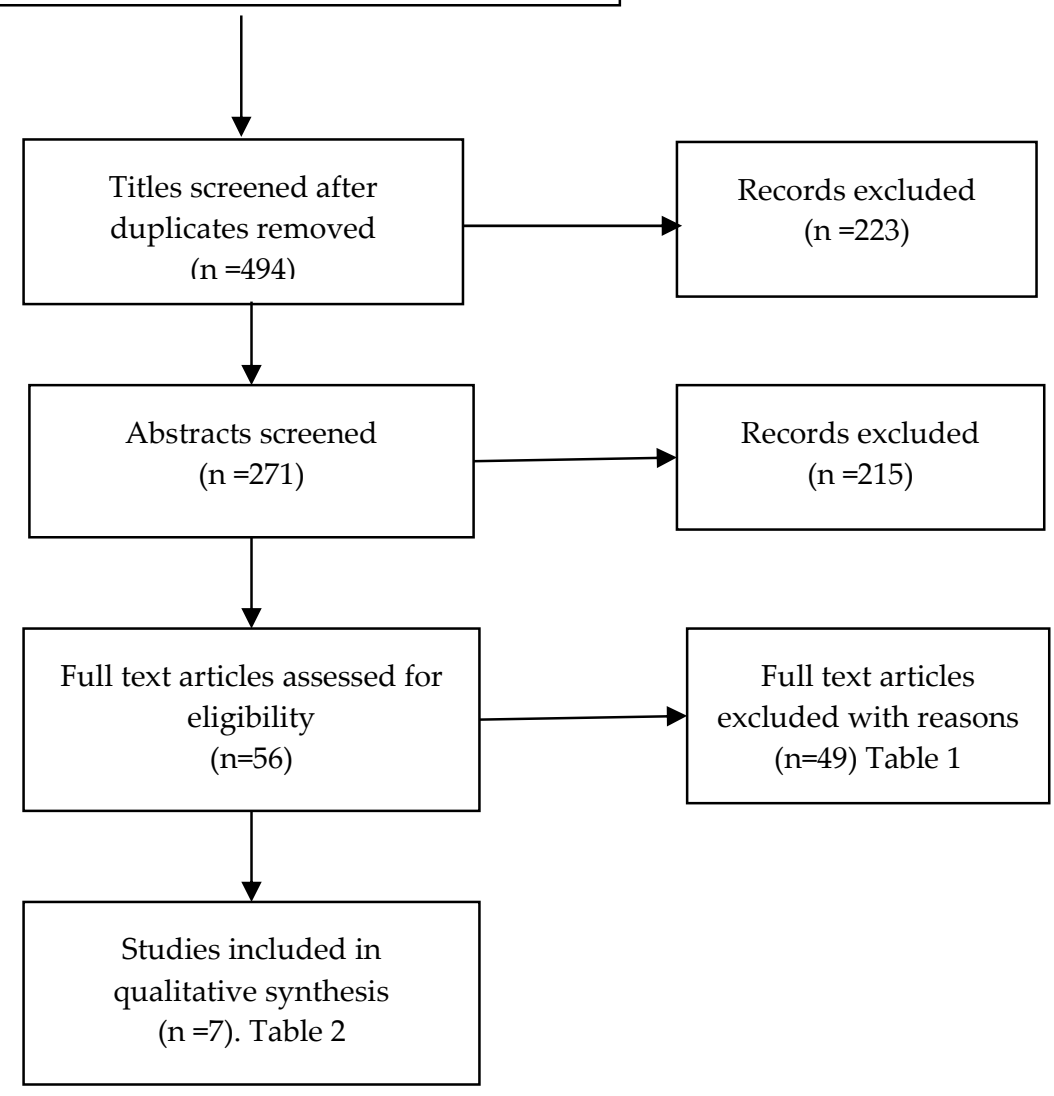

Figure 2. Selection process of papers for systematic review. 
From the excluded manuscripts, 6 did not have control groups, 1 did not sample the endometrium, 3 papers used the same results in different publications, 3 papers were retrospective studies, 7 used the sampling methods to establish threshold values for diagnosis of endometritis, 12 did not report the pregnancy rates after sampling, and 16 investigated the impact of endometritis on pregnancy rates.

Seven studies including 3693 animals (sampled $=1254$; not sampled $=2409$ ) met the inclusion criteria. The characteristics of the selected studies are summarized in Table 2. Four of these were prospective cohort studies $[18,20,27,28]$. Two studies were randomized controlled studies $[29,30]$ and one a case control study [31]. In the prospective cohort studies, the experiments compared the effect of CB [20], UL [18], or UL and EB [27] with no endometrial sampling. Within the randomized studies, one study compared EB [29] and the other compared UL [30] with no endometrial sampling. In the case control study [31], the effect of EB on the first AI pregnancy rates was compared with non-biopsied cows at 150 DIM (days in milk).

Table 1. Characteristics of studies excluded.

\begin{tabular}{|c|c|c|}
\hline Study & Type of Intervention & Criteria \\
\hline Bacha and Regassa, 2010 [32] & UL & $\begin{array}{c}\text { Pregnancy rate only from cows with endometritis } \\
\text { diagnosed by cytology }\end{array}$ \\
\hline $\begin{array}{l}\text { Baranski et al., (a) } 2012 \text { [33] and (b) } \\
2013 \text { [34] }\end{array}$ & $\mathrm{CB}$ & $\begin{array}{l}\text { (a) Established threshold values for diagnosis of subclinical } \\
\text { endometritis. (b) Determined the impact of cytological } \\
\text { endometritis on pregnancy rates }\end{array}$ \\
\hline Barlund et al., 2008 [7] & $\mathrm{CB}, \mathrm{UL}$ & $\begin{array}{l}\text { Compared thresholds of different techniques for diagnosis } \\
\text { of endometritis }\end{array}$ \\
\hline Barrio et al., 2015 [35] & $\mathrm{CB}$ & $\begin{array}{l}\text { Diagnosed subclinical endometritis by Cytobrush and } \\
\text { determined the impact on reproductive performance }\end{array}$ \\
\hline Bicalho et al., 2016 [36] & EB & Pregnancy rate not mentioned \\
\hline Binelli et al., 2015 [37] & EB & $\begin{array}{l}\text { Transcriptome uterine analysis was retrospectively } \\
\text { performed in pregnant and non-pregnant cows }\end{array}$ \\
\hline Bolzenius et al., 2016 [38] & EB & Pregnancy rate not compared with non-biopsied cows \\
\hline Brodzki et al., (a) 2015 [39], (b) 2014 [40], & (a) UL, CB, (b) CB & $\begin{array}{l}\text { (a) Pregnancy rate not described. (b) Pregnancy rates were } \\
\text { related to presence/absence of subclinical endometritis } \\
\text { (a) Evaluate the cytological endometritis diagnosed by }\end{array}$ \\
\hline Carneiro et al., (a) 2013 [41], (b) 2014 [42] & (a)UL, (b) CB & $\begin{array}{l}\text { uterine lavage in reproductive performance. (b)Evaluate } \\
\text { reproductive performance in cows diagnosed with } \\
\text { subclinical endometritis }\end{array}$ \\
\hline $\begin{array}{l}\text { Chapwanya et al., } 2009 \text { [43]; } 2010 \text { [15]; } \\
\qquad 2012 \text { [44] }\end{array}$ & EB & No control group. Same data in three studies \\
\hline Cheong et al., (a) 2011 [45], (b) 2012 [46] & UL & $\begin{array}{l}\text { (a) Determine risk factors for subclinical endometritis and } \\
\text { its effect on reproductive performance. (b) Determine the } \\
\text { use of leukocyte esterase strip as indicator of endometritis }\end{array}$ \\
\hline Couto et al., 2013 [47] & $\mathrm{CB}, \mathrm{UL}$ & $\begin{array}{c}\text { Used uterine fluid to measure leukocyte esterase activity to } \\
\text { diagnose endometritis }\end{array}$ \\
\hline de Biase et al., 2018 [48] & EB & $\begin{array}{l}\text { Diagnosis of infectious agents using EB but pregnancy rate } \\
\text { was not reported }\end{array}$ \\
\hline de Boer et al., 2015 [49] & $\mathrm{CB}$ & $\begin{array}{c}\text { Assessed \% PMN cells and PR given on cows } \\
\text { with endometritis }\end{array}$ \\
\hline De Sa et al., 2017 [50] & $\mathrm{EB}$ & $\begin{array}{l}\text { Assess transcriptome analysis of endometrium on day } 6 \\
\text { from pregnant and non-pregnant cows }\end{array}$ \\
\hline Denis-Robichaud, 2015 [51] & $\mathrm{CB}$ & $\begin{array}{l}\text { Used the leukocyte esterase test for diagnosis of } \\
\text { endometrial health and as predictor of pregnancy status in } \\
\text { cows with endometritis }\end{array}$ \\
\hline Gabai et al., 2019 [52] & CB and UL & Pregnancy rate not described \\
\hline $\begin{array}{l}\text { Kasimanickam et al., (a) } 2004 \text { [12], (b) } \\
2006 \text { [53] }\end{array}$ & (a) CB (b) None & $\begin{array}{l}\text { (a) Validated cytology for diagnosis of endometritis (b) They } \\
\text { did not use any endometrial sampling procedure }\end{array}$ \\
\hline Katagiri et al., 2006 [54] & $\mathrm{EB}$ & Pregnancy rate given but no control group \\
\hline Lopez et al., 2012 [2] & $\mathrm{CB}$ & $\begin{array}{l}\text { Pregnancy rate associated with endometrial } \\
\text { health postpartum }\end{array}$ \\
\hline
\end{tabular}


Table 1. Cont.

\begin{tabular}{|c|c|c|}
\hline Study & Type of Intervention & Criteria \\
\hline Machado et al., 2012 [55] & UL & Pregnancy rate associated with endometrial health \\
\hline Madoz et al., 2013 [56] & $\mathrm{CB}$ & $\begin{array}{l}\text { Used endometrial cells to establish cut off values for } \\
\text { endometritis in grazing cows }\end{array}$ \\
\hline McDougall et al., 2011 [57] & $\mathrm{CB}$ & Pregnancy rate correlated with \% PMN \\
\hline Nehru et al., 2019 [58] & CB and UL & Pregnancy rate reported but no control group \\
\hline Pascottini et al., 2015 [13] & $\mathrm{CB}, \mathrm{CT}$ & Pregnancy rate not described \\
\hline Pascottini et al., 2016 [59] & $\mathrm{CT}$ & Pregnancy rate not reported in non-sampled heifers \\
\hline Pascottini et al., 2017 [60] & $\mathrm{CT}$ & Pregnancy rate not reported in non-sampled cows \\
\hline Plontzke et al., 2010 [9] & $\mathrm{CB}$ & $\begin{array}{c}\text { Pregnancy rates associated with \% PMN in } \\
\text { subclinical endometritis }\end{array}$ \\
\hline Prunner et al., 2014 [61] & $\mathrm{CB}$ & Pregnancy rate determined by postpartum uterine health \\
\hline Rhoads et al., 2008 [24] & EB & Pregnancy rate not reported \\
\hline Ricci et al., 2015 [62] & UL & $\begin{array}{c}\text { Pregnancy rate associated with \%PMN in } \\
\text { subclinical endometritis }\end{array}$ \\
\hline Salasel et al., 2010 [63] & UL & $\begin{array}{l}\text { Pregnancy rate associated with subclinical endometritis and } \\
\text { risk factors }\end{array}$ \\
\hline Santos et al., 2009 [64] & UL & Pregnancy rates associated with \% PMN in Bos indicus cows \\
\hline Scolari et al., 2017 [65] & $\mathrm{EB}$ & $\begin{array}{l}\text { Assess transcriptome analysis of endometrium on day } 6 \\
\text { from pregnant and non-pregnant cows }\end{array}$ \\
\hline Senosy et al., 2012; [66] & $\mathrm{CB}$ & Fertility rates based on uterine health diagnosed postpartum \\
\hline Sens and Heuwieser, 2013 [67] & $\mathrm{CB}$ & No control group \\
\hline Studer et al., 1978 [6] & $\mathrm{EB}$ & Pregnancy rate is not mentioned after procedure \\
\hline Van Schyndel et al., 2019 [68] & $\mathrm{CB}, \mathrm{UL}$ & $\begin{array}{l}\text { Compared cytologies for diagnosis of subclinical } \\
\text { endometritis, but pregnancy rate is not described }\end{array}$ \\
\hline Werner et al., 2012 [69] & $\mathrm{CB}$ & Pregnancy rate is not mentioned after procedure \\
\hline Westerman et al., 2010 [3] & $\mathrm{CB}$ & Pregnancy rate is not mentioned after procedure \\
\hline Zaayer et al., 1986 [70] & $\mathrm{EB}$ & Pregnancy rate is not mentioned after procedure \\
\hline
\end{tabular}

UL: uterine lavage; CB: cytobrush; EB: endometrial biopsy; CT: cytotape; PMN: polymorphonuclear cells; PR: pregnancy rate; SCE: subclinical endometritis.

Table 2. Pregnancy rates after endometrial sampling in cattle.

\begin{tabular}{|c|c|c|c|c|c|c|c|}
\hline Author & Study Design & Sampled $(n)$ & Control $(n)$ & Intervention (\#) & $\begin{array}{c}\text { Interval } \\
\text { Procedure-Breeding }\end{array}$ & PR Sampled (\%) & $\begin{array}{c}\text { PR Control } \\
(\%)\end{array}$ \\
\hline $\begin{array}{l}\text { Etheringthon et al. } \\
[29])\end{array}$ & RCS & 92 & 69 & $\begin{array}{l}\text { EB } \\
(4)\end{array}$ & $\mathrm{NM}$ & 37 & 39 \\
\hline Kauffman et al. [20] & CS & 201 & 103 & $\begin{array}{l}\text { CB } \\
\text { (1) }\end{array}$ & $4 \mathrm{~h}$ & 43.3 & 41.7 \\
\hline Cheong et al. [18] & CS & 705 & 1992 & $\begin{array}{l}\mathrm{UL} \\
(1)\end{array}$ & $19.4 \mathrm{~d}(\mathrm{SEM}=0.4)$ & $\begin{array}{l}\text { PRI } 31.2 \\
\text { MUL } 29.1\end{array}$ & $\begin{array}{l}36.5 \\
28.1\end{array}$ \\
\hline Goshen et al. [31] & $\mathrm{CC}$ & 44 & 157 & $\begin{array}{l}\text { EB } \\
(1)\end{array}$ & $\begin{array}{c}40.5 \mathrm{~d} \\
(5-111)\end{array}$ & 44.4 & 38.9 \\
\hline Pugliesi et al. [27] & CS & 73 & 37 & $\begin{array}{l}\text { EB (1) } \\
\text { UL (1) }\end{array}$ & $6 d^{*}$ & $\begin{array}{l}\text { EB 31.6; UL 28.6 ** } \\
\text { EB 26.3; UL } 17.1^{* * *}\end{array}$ & $\begin{array}{l}40.5^{* *} \\
40.5^{* * *}\end{array}$ \\
\hline Thome et al. [30] & RCS & 93 & 35 & UL (1) & $4 \mathrm{~h}$ after $\mathrm{AI}$ & $57 \pm 5.1$ & $54 \pm 8.4$ \\
\hline Martins et al. [28]) & CS & 46 & 16 & UL (1) & $6 \mathrm{~d}, 3 \mathrm{~d}$ and $0.5 \mathrm{~d}^{* * *}$ & $\begin{array}{c}\text { Day } 1(60) \\
\text { Day } 4(29.4) \\
\text { Day } 7(37.5)\end{array}$ & 62.5 \\
\hline
\end{tabular}

RCS: randomized controlled study; CS: cohort study; CC: case control study; UL: uterine lavage; EB: endometrial biopsy; CB: cytobrush; AI artificial insemination; ${ }^{*}$ time of breeding after intervention; ${ }^{* *} 30$ days of pregnancy assessment after breeding; ${ }^{* * *} 60$ days of pregnancy assessment after breeding ${ }^{* * *}$ interval from UL to embryo transfer (ET)(day 7.5 postoestrus).

\subsection{Uterine Lavage Studies}

Cheong et al. [18] performed a prospective cohort study comparing the effect of UL to collect endometrial cells $(n=705)$ with no endometrial sampling $(n=1992)$ studying the reproductive performance of healthy Holstein cows. The selection criteria included primiparous and multiparous cows within 40-60 d postpartum, not inseminated without vaginal discharge or systemic illness. The reproductive performance was assessed during a 210-day period after endometrial sampling. The mean interval from sampling to first 
service was 19.4 days. In primiparous cows, the PR to first service was lower in sampled cows compared to cows which were not sampled $(31.2 \%$ vs. $36.5 \%$ OR for pregnancy $=$ 1.03; 95\% C.I. 0.80-1.33; $p=0.82$ ), whereas in multiparous cows, PR was similar in both groups ( $29.1 \%$ and $28.1 \%$ sampled and non-sampled cows, respectively).

In a randomized controlled study, Thome et al. [30] evaluated the effect of collecting endometrial cells by UL in postpartum Nellore cows (50-70 days postpartum). In 35 cows, the UL was performed $4 \mathrm{~h}$ after timed artificial insemination, while 93 were not sampled. No significant differences in PR were found between sampled and non-sampled groups ( $54.2 \%$ vs. $56.7 \%$, respectively, $p>0.05$ ).

Martins et al. [28] in a prospective cohort study compared the PR after ET on day 7.5 in non-lactating, cycling Nellore cows after having UL on days 1, 4, and 7 ( $n=46$; day 0 ; estrous detection) with control cows $(n=16)$. Control and day 1 cows $(62.5 \%$ and $60 \%$, respectively) had higher PR than cows sampled on day 4 and day $7(29.4 \%$ and $37.5 \%$, respectively) $(p=0.06)$.

\subsection{Cytobrush Studies}

In a prospective cohort study, Kaufman et al. [19] evaluated the effect of CB sampling the endometrium $4 \mathrm{~h}$ after artificial insemination on pregnancy rate to first service in cows calved at least 65 days. PR was similar for sampled and non-sampled cows $(43.3 \%$ vs. $41.7 \%, p>0.05)$, although significantly higher in primiparous than multiparous cows (54.3 vs. $38.5 \%, p<0.05)$.

\subsection{Endometrial Biopsy Studies}

In a case control study, Goshen et al. [31] randomly selected 54 Holstein cows calved approximately 67 days to undergo EB; 157 control cows were paired with sampled cows. The effect of the biopsy on PR to first artificial insemination was calculated using binary logistic regression. The interval from biopsy to first AI was 40.5 days (range 5-111 days). The PR and days from calving to conception in biopsied cows (44.4\%; 147.3 days) did not differ significantly from those in control cows (38.9\%, 150.8 days).

Etherington et al. [29] conducted a randomized controlled trial on 130 postpartum dairy cows and evaluated the effect of postpartum EB between days 26 and 40 postpartum on PR to first $\mathrm{AI}$ and calving to conception interval. $\mathrm{EB}$ increased the interval from calving to first service ( 89 days biopsied cows versus 81.5 days for control cows; $p=0.07$ ). However, the PR to first AI for biopsied cows $(n=92 ; 37 \%)$ was not significantly different from non-biopsied cows $(n=69 ; 39 \%)$.

In a prospective cohort study, Pugliesi et al. [27] evaluated the effect of UL ( $n=35)$ and $\mathrm{EB}(n=38)$ from the horn contralateral to the corpus luteum (CL) on day 6 after timed artificial insemination on pregnancy rates on days 30 and 60 in multiparous Bos indicus cows. After the procedure, all cows received a non-steroidal anti-inflammatory treatment (flunixin meglumine, $1.1 \mathrm{mg} / \mathrm{kg} \mathrm{bw}, \mathrm{IM}$ ) and an antibiotic (penicillin-streptomycin 6,000,000 IU). The PR were similar $(p>0.1)$ for UL, EB, and non-sampled cows on day $30(28.6,31.6$ and $40.5 \%$, respectively), but the pregnancy rates decreased significantly in UL cows $(p<0.004)$ compared to control and EB cows on fay 60 (17.1\%, 26.3\%, and $40.5 \%$, respectively).

\section{Discussion}

The aim of this review was to determine the likely impact of endometrial sampling procedures on the subsequent pregnancy rates of treated cattle. The results indicate that PR were similar for sampled and non-sampled animals using $\mathrm{CB}, \mathrm{UL}$, and $\mathrm{EB}$ if the procedure was performed before breeding or a few hours after insemination. However, it was affected if it was performed during early diestrus. The heterogeneity of the selected studies in terms of type of cattle used (dairy and beef), physiological stage during sampling (early postpartum [29] or late postpartum $>45$ days [31], and the interval from sampling to breeding (i.e., $4 \mathrm{~h}[20,30]$ or $20-40$ days [31] did not allow comparison between different methods to determine whether one method affects the PR more than any other. The 
CT $[59,60]$ studies were not assessed as pregnancy rates from untreated controls were not included in the study.

These results suggest that perturbations caused after endometrial sampling might induce acute changes in the endometrial environment, but the ability to support embryo development and maintain a pregnancy is recovered. As an indirect indicator of uterine response to artificial insemination [71], changes in uterine blood flow have been measured using color Doppler transrectal ultrasonography. An increase in uterine blood flow was observed within $4 \mathrm{~h}$ of the procedure, which returned to baseline by $24 \mathrm{~h}$, indicating that these procedures may induce a short acute inflammatory response. Although previous reports indicate that performing UL induces endometrial irritation caused either by the fluid [72] or by the device [73], studies in mares [74,75] and women [76] have demonstrated that UL did not induce significant morphological changes to the endometrial tissue [77]. Just before artificial insemination, Pascottini et al. collected endometrial cells using CT in nulliparous heifers [59] and multiparous cows [60], and then observed pregnancy rates of $62 \%$ and $43 \%$, respectively, which are similar to pregnancy rates reported in non-sampled dairy cows [78]. Similarly, Cheong et al. [18] and Thome et al. [30] performed UL $4 \mathrm{~h}$ after insemination without affecting pregnancy rates which is consistent with results in other species such as horses where fertility is not reduced by post-breeding UL [79]. In ET studies, CB sampling one cycle before transfer (74) or collecting UL on day 1 postoestrus during the ongoing cycle [28] did not affect the pregnancy rates after ET. Therefore, it seems likely that recovering endometrial fluid or cells did not adversely affect fertilization and early embryo development but the time of sampling should be considered to allow the endometrial environment to recover after it is disturbed so as to not affect pregnancy outcome.

Sampling the endometrium close to the time of embryo arrival in the uterine horn (days 4-7) adversely affects embryo survival. In this review, one study [27] assessed the PR after performing UL or EB from the horn contralateral to the CL six days after insemination. Although PR were not significantly different on day 30 between sampled and non-sampled cows, the PR on day 60 were significantly lower in cows that had UL performed 6 days after insemination. In another study [28], the PR were reduced by about $50 \%$ by performing UL on day 4 or day 7 before ET (day 7.5 postoestrus). This increase in embryo and early foetal mortality can be attributed to either the early removal of unknown histotrophic factors needed for conceptus survival or by the endometrial inflammatory reaction and the subsequent influx of plasma proteins into the uterine lumen caused by the procedure [28]. The histotroph contains proteins, amino acids, and lipids essential for the support of early embryo development [80], and any induced change in the histotroph as a result of endometrial sampling may subsequently adversely affect early placental development [81].

One might speculate that after using more invasive procedures such as EB, the trauma and subsequent inflammatory and wound healing reaction will adversely affect embryo development and survival. However, the findings from the studies in this review showed that PR after EB were not affected by the type of cattle (beef or dairy), uterine and ovarian stage (uterine involution/anoestrus), parity (heifers or multiparous cows), number of interventions (single or multiple procedures), and the type of device used. Etherington et al. [29] found that cows that underwent EB from both horns on day 26 and/or day 40 had a longer calving to conception interval compared to non-biopsied cows (135 vs. 115 days, respectively, $p=0.03$ ), and prolonged interval from calving to first service compared to non-biopsied cows (89 vs. 81 days, respectively, $p=0.07$ ). However, they did not find significant variation in the pregnancy rates between biopsied and non-biopsied cows (37\% vs. $39 \%$, respectively). In a larger study of high-yield Holstein cows $(n=54)$, Goshen et al. [31] evaluated the effect of biopsying high-yield milking cows after uterine involution (between 44 and 104 days postpartum) on pregnancy rates. They did not find significant differences in PR between biopsied and control cows (44.4 vs. 38.9, respectively, $p=0.146$,). These results suggest that performing biopsies before the completion of uterine involution 
may slow down the complete recovery of the endometrium postpartum, but if the biopsy is performed after involution, it apparently does not affect the conception rates.

In other studies that were not considered in the systematic review for not fulfilling the selection criteria (Table 1), pregnancy rates have been assessed after EB. Chapwanya et al. [15] evaluated the effect of three consecutive endometrial biopsies in the same uterine horn at days 15,30 , and 60 on pregnancy rates in postpartum cows $(n=13)$. They reported pregnancy rates of $77 \%$ performing the first AI 30 days after the last biopsy. Similarly, Rhoads et al. [24] collected three EB per cow $(n=33)$ from both horns at different times ( 3 days before oestrus, during oestrus, and 4 days after insemination) and reported PR in biopsied cows of $52 \%$, which is considered within the normal range of PR in dairy postpartum cows. Similarly, Meikle et al. [82] and Katagiri et al. [83] performed four and six EB, respectively, within the oestrus cycle in the same animal and found that the majority of biopsied animals became pregnant within the first two detected oestrus after sampling ( $n=5 / 7$ PR 71\% [82] and $n=14 / 25$ PR 56\% [83]), although the interval from sampling to onset of oestrus or the number of days to return to cyclicity was not mentioned. Collectively, these reports suggest that biopsy is a safe procedure which does not have a deleterious effect on fertility and PR.

\section{Conclusions}

The results of this systematic review show that invasive methods of endometrial sampling can be performed before breeding or within the first day postoestrus without affecting pregnancy rates in cattle with a healthy endometrium. However, caution must be taken since comparison between studies were not possible, and further studies with much larger numbers of cattle are needed to verify the effect of endometrial sampling on pregnancy rates.

Author Contributions: All authors contributed equally to design and critical revision of the manuscript. Conceptualization, O.R.-G., R.S.M., M.K.H., and M.M.; methodology, O.R.-G. and R.S.M.; software, O.R.-G.; validation, O.R.-G., R.S.M., C.J., N.S., and M.M.; formal analysis, O.R.-G., R.S.M., C.J., N.S., J.H., M.K.H., and M.M.; investigation, O.R.-G., R.S.M., and J.H.; resources, R.S.M., N.S., M.K.H., and M.M.; data curation, O.R.-G., R.S.M., and C.J.; writing — original draft preparation, O.R.-G.; writing—-review and editing, R.S.M., N.S., C.J., J.H., M.K.H., and M.M.; visualization, O.R.-G.; supervision, J.H., M.K.H., and M.M.; project administration, M.M.; funding acquisition, O.R.-G., M.K.H., and M.M. All authors have read and agreed to the published version of the manuscript.

Funding: This research was supported by the School of Veterinary Science, the University of Queensland, Australia and COLCIENCIAS, Colombia.

Institutional Review Board Statement: Not applicable.

Informed Consent Statement: Not applicable.

Acknowledgments: Osvaldo Bogado Pascottini for the Cytotape images.

Conflicts of Interest: The authors declare no conflict of interest.

\section{References}

1. Sheldon, I.M.; Lewis, G.S.; LeBlanc, S.; Gilbert, R.O. Defining postpartum uterine disease in cattle. Theriogenology 2006, 65, 1516-1530. [CrossRef]

2. Lopez-Helguera, I.; Lopez-Gatius, F.; Garcia-Ispierto, I. The influence of genital tract status in postpartum period on the subsequent reproductive performance in high producing dairy cows. Theriogenology 2012, 77, 1334-1342. [CrossRef]

3. Westermann, S.; Drillich, M.; Kaufmann, T.B.; Madoz, L.V.; Heuwieser, W. A clinical approach to determine false positive findings of clinical endometritis by vaginoscopy by the use of uterine bacteriology and cytology in dairy cows. Theriogenology 2010, 74, 1248-1255. [CrossRef]

4. McDougall, S.; Macaulay, R.; Compton, C. Association between endometritis diagnosis using a novel intravaginal device and reproductive performance in dairy cattle. Anim. Reprod. Sci. 2007, 99, 9-23. [CrossRef]

5. Bonnett, B.N.; Martin, S.W. Path analysis of peripartum and postpartum events, rectal palpation findings, endometrial biopsy results and reproductive performance in Holstein-Friesian dairy cows. Prev. Vet. Med. 1995, 21, 279-288. [CrossRef] 
6. Studer, E.; Morrow, D.A. Postpartum evaluation of bovine reproductive potential: Comparison of findings from genital tract examination per rectum, uterine culture, and endometrial biopsy. J. Am. Vet. Med. Assoc. 1978, 172, 489-494. [PubMed]

7. Barlund, C.S.; Carruthers, T.D.; Waldner, C.L.; Palmer, C.W. A comparison of diagnostic techniques for postpartum endometritis in dairy cattle. Theriogenology 2008, 69, 714-723. [CrossRef] [PubMed]

8. Meira, E.B., Jr.; Henriques, L.C.; Sa, L.R.; Gregory, L. Comparison of ultrasonography and histopathology for the diagnosis of endometritis in Holstein-Friesian cows. J. Dairy Sci. 2012, 95, 6969-6973. [CrossRef]

9. Plontzke, J.; Madoz, L.V.; De la Sota, R.L.; Drillich, M.; Heuwieser, W. Subclinical endometritis and its impact on reproductive performance in grazing dairy cattle in Argentina. Anim. Reprod. Sci. 2010, 122, 52-57. [CrossRef]

10. de Boer, M.W.; LeBlanc, S.J.; Dubuc, J.; Meier, S.; Heuwieser, W.; Arlt, S.; Gilbert, R.O.; McDougall, S. Invited review: Systematic review of diagnostic tests for reproductive-tract infection and inflammation in dairy cows1. J. Dairy Sci. 2014, 97, 3983-3999. [CrossRef]

11. Pascottini, O.B.; Hostens, M.; Dini, P.; Vandepitte, J.; Ducatelle, R.; Opsomer, G. Comparison between cytology and histopathology to evaluate subclinical endometritis in dairy cows. Theriogenology 2016, 86, 1550-1556. [CrossRef] [PubMed]

12. Kasimanickam, R.; Duffield, T.F.; Foster, R.A.; Gartley, C.J.; Leslie, K.E.; Walton, J.S.; Johnson, W.H. Endometrial cytology and ultrasonography for the detection of subclinical endometritis in postpartum dairy cows. Theriogenology 2004, 62, 9-23. [CrossRef]

13. Pascottini, O.B.; Dini, P.; Hostens, M.; Ducatelle, R.; Opsomer, G. A novel cytologic sampling technique to diagnose subclinical endometritis and comparison of staining methods for endometrial cytology samples in dairy cows. Theriogenology 2015, 84, 1438-1446. [CrossRef] [PubMed]

14. Bonnett, B.N.; Miller, R.B.; Martin, S.W.; Etherington, W.G.; Buckrell, B.C. Endometrial biopsy in Holstein-Friesian dairy cows. II. Correlations between histological criteria. Can. J. Vet. Res. 1991, 55, 162-167.

15. Chapwanya, A.; Meade, K.G.; Narciandi, F.; Stanley, P.; Mee, J.F.; Doherty, M.L.; Callanan, J.J.; O’Farrelly, C. Endometrial biopsy: A valuable clinical and research tool in bovine reproduction. Theriogenology 2010, 73, 988-994. [CrossRef] [PubMed]

16. Beltman, M.E.; Mullen, M.P.; Elia, G.; Hilliard, M.; Diskin, M.G.; Evans, A.C.; Crowe, M.A. Global proteomic characterization of uterine histotroph recovered from beef heifers yielding good quality and degenerate day 7 embryos. Domest. Anim. Endocrinol. 2014, 46, 49-57. [CrossRef]

17. Fischer, C.; Drillich, M.; Odau, S.; Heuwieser, W.; Einspanier, R.; Gabler, C. Selected pro-inflammatory factor transcripts in bovine endometrial epithelial cells are regulated during the oestrous cycle and elevated in case of subclinical or clinical endometritis. Reprod. Fertil. Dev. 2010, 22, 818-829. [CrossRef] [PubMed]

18. Cheong, S.H.; Nydam, D.V.; Galvao, K.N.; Crosier, B.M.; Gilbert, R.O. Effects of diagnostic low-volume uterine lavage shortly before first service on reproductive performance, culling and milk production. Theriogenology 2012, 77, 1217-1222. [CrossRef] [PubMed]

19. Bicalho, M.L.S.; Machado, V.S.; Higgins, C.H.; Lima, F.S.; Bicalho, R.C. Genetic and functional analysis of the bovine uterine microbiota. Part I: Metritis versus healthy cows. J. Dairy Sci. 2017, 100, 3850-3862. [CrossRef]

20. Kaufmann, T.B.; Drillich, M.; Tenhagen, B.A.; Forderung, D.; Heuwieser, W. Prevalence of bovine subclinical endometritis 4 h after insemination and its effects on first service conception rate. Theriogenology 2009, 71, 385-391. [CrossRef]

21. Ghasemi, F.; Gonzalez-Cano, P.; Griebel, P.J.; Palmer, C. Proinflammatory cytokine gene expression in endometrial cytobrush samples harvested from cows with and without subclinical endometritis. Theriogenology 2012, 78, 1538-1547. [CrossRef] [PubMed]

22. Ramirez-Garzon, O.; Satake, N.; Lyons, R.E.; Hill, J.; Holland, M.K.; McGowan, M. Endometrial biopsy in Bos indicus beef heifers. Reprod. Domest. Anim. 2017, 52, 526-528. [CrossRef]

23. Helfrich, A.L.; Reichenbach, H.-D.; Meyerholz, M.M.; Schoon, H.-A.; Arnold, G.J.; Fröhlich, T.; Weber, F.; Zerbe, H. Novel sampling procedure to characterize bovine subclinical endometritis by uterine secretions and tissue. Theriogenology 2020, 141, 186-196. [CrossRef]

24. Rhoads, M.L.; Meyer, J.P.; Lamberson, W.R.; Keisler, D.H.; Lucy, M.C. Uterine and hepatic gene expression in relation to days postpartum, estrus, and pregnancy in postpartum dairy cows. J. Dairy Sci. 2008, 91, 140-150. [CrossRef]

25. Watson, E.D.; Sertich, P.L. Effect of repeated collection of multiple endometrial biopsy specimens on subsequent pregnancy in mares. J. Am. Vet. Med. Assoc. 1992, 201, 438-440. [PubMed]

26. Sar-Shalom Nahshon, C.; Sagi-Dain, L.; Wiener-Megnazi, Z.; Dirnfeld, M. The impact of intentional endometrial injury on reproductive outcomes: A systematic review and meta-analysis. Hum. Reprod. Update 2018, 25, 95-113. [CrossRef] [PubMed]

27. Pugliesi, G.; Scolari, S.C.; Mesquita, F.S.; Maturana Filho, M.; Araujo, E.R.; Cardoso, D.; Sales, J.N.; Martin, I.; Sa Filho, M.; Bertan, C.M.; et al. Impact of probing the reproductive tract during early pregnancy on fertility of beef cows. Reprod. Domest. Anim. 2014, 49, e35-e39. [CrossRef] [PubMed]

28. Martins, T.; Pugliesi, G.; Sponchiado, M.; Gonella-Diaza, A.M.; Ojeda-Rojas, O.A.; Rodriguez, F.D.; Ramos, R.S.; Basso, A.C.; Binelli, M. Perturbations in the uterine luminal fluid composition are detrimental to pregnancy establishment in cattle. J. Anim. Sci. Biotechnol. 2018, 9, 70. [CrossRef]

29. Etherington, W.G.; Martin, S.W.; Bonnett, B.; Johnson, W.H.; Miller, R.B.; Savage, N.C.; Walton, J.S.; Montgomery, M.E. Reproductive performance of dairy cows following treatment with cloprostenol 26 and/or 40 days postpartum: A field trial. Theriogenology 1988, 29, 565-575. [CrossRef] 
30. Thome, H.E.; de Arruda, R.P.; de Oliveira, B.M.; Maturana Filho, M.; de Oliveira, G.C.; Guimaraes Cde, F.; de Carvalho Balieiro, J.C.; Azedo, M.R.; Pogliani, F.C.; Celeghini, E.C. Uterine lavage is efficient to recover endometrial cytology sample and does not interfere with fertility rate after artificial insemination in cows. Theriogenology 2016, 85, 1549-1554. [CrossRef]

31. Goshen, T.; Galon, N.; Arazi, A.; Shpigel, N. The effect of uterine biopsy on reproductive performance of dairy cattle: A case control study. Isr. J. Vet. Med. 2012, 67, 34-38.

32. Bacha, B.; Regassa, F.G. Subclinical endometritis in Zebu x Friesian crossbred dairy cows: Its risk factors, association with subclinical mastitis and effect on reproductive performance. Trop. Anim. Health Prod. 2010, 42, 397-403. [CrossRef] [PubMed]

33. Baranski, W.; Podhalicz-Dziegielewska, M.; Zdunczyk, S.; Janowski, T. The diagnosis and prevalence of subclinical endometritis in cows evaluated by different cytologic thresholds. Theriogenology 2012, 78, 1939-1947. [CrossRef]

34. Barański, W.; Zduńczyk, S.; Janowski, T. Reproductive performance of cows with subclinical endometritis diagnosed by different cytological thresholds in the postpartum period. Tierarztl Prax Ausg G Grosstiere Nutztiere 2013, 41, 15-19. [PubMed]

35. Barrio, M.; Vigo, M.; Quintela, L.A.; Becerra, J.J.; Garcia-Herradon, P.J.; Martinez-Bello, D.; Fernandez-Sanchez, F.I.; Prieto, A.; Cainzos, J.; Pena, A.I. Influence of subclinical endometritis on the reproductive performance of dairy cows. Span. J. Agric. Res. 2015, 13. [CrossRef]

36. Bicalho, M.L.S.; Lima, F.S.; Machado, V.S.; Meira, E.B.; Ganda, E.K.; Foditsch, C.; Bicalho, R.C.; Gilbert, R.O. Associations among Trueperella pyogenes, endometritis diagnosis, and pregnancy outcomes in dairy cows. Theriogenology 2016, 85, 267-274. [CrossRef]

37. Binelli, M.; Scolari, S.C.; Pugliesi, G.; Van Hoeck, V.; Gonella-Diaza, A.M.; Andrade, S.C.S.; Gasparin, G.R.; Coutinho, L.L. The Transcriptome Signature of the Receptive Bovine Uterus Determined at Early Gestation. PLoS ONE 2015, 10, e0122874. [CrossRef]

38. Bolzenius, J.K.; Cushman, R.A.; Perry, G.A. Expression of $\mathrm{Na}(+) / \mathrm{H}(+)$ exchanger isoforms 1, 2, 3, and 4 in bovine endometrium and the influence of uterine $\mathrm{pH}$ at time of fixed-time AI of pregnancy success. Anim. Reprod. Sci. 2016, 171, 98-107. [CrossRef] [PubMed]

39. Brodzki, P.; Brodzki, A.; Kurek, L.; Marczuk, J.; Tatara, M.R. Endometrial Cytology At Luteal And Follicular Phases Of The Ovarian Cycle In Cows. Ann. Anim. Sci. 2015, 15, 107-117. [CrossRef]

40. Brodzki, P.; Brodzki, A.; Kostro, K.; Kurek, L.; Marczuk, J.; Krakowski, L. Cytological image of the endometrium in cows in follicular and luteal phases of the ovarian cycle and in cows with follicular and luteal ovarian cysts. Bull. Vet. Inst. Pulawy 2014, 58, 141-147. [CrossRef]

41. Carneiro, L.C.; Mendes, F.M.; Oliveira, R.S.B.R.; Silva Pádua, M.F.; Ferreira, A.F.; Saut, J.P.E.; Santos, R.M. Incidence of cytological endometritis and its effects on reproductive performance in nelore beef cows. Arq. Bras. Med. Vet. Zootec. 2013, 65, 742-748. [CrossRef]

42. Carneiro, L.C.; Ferreira, A.F.; Padua, M.; Saut, J.P.; Ferraudo, A.S.; Santos, R.M.d. Incidence of subclinical endometritis and its effects on reproductive performance of crossbred dairy cows. Trop. Anim. Health Prod. 2014, 46, 1435-1439. [CrossRef]

43. Chapwanya, A.; Meade, K.G.; Doherty, M.L.; Callanan, J.J.; Mee, J.F.; O’Farrelly, C. Histopathological and molecular evaluation of Holstein-Friesian cows postpartum: Toward an improved understanding of uterine innate immunity. Theriogenology 2009, 71, 1396-1407. [CrossRef]

44. Chapwanya, A.; Meade, K.G.; Foley, C.; Narciandi, F.; Evans, A.C.O.; Doherty, M.L.; Callanan, J.J.; O’Farrelly, C. The postpartum endometrial inflammatory response: A normal physiological event with potential implications for bovine fertility. Reprod. Fertil. Dev. 2012, 24, 1028-1039. [CrossRef]

45. Cheong, S.H.; Nydam, D.V.; Galvão, K.N.; Crosier, B.M.; Gilbert, R.O. Cow-level and herd-level risk factors for subclinical endometritis in lactating Holstein cows. J. Dairy Sci. 2011, 94, 762-770. [CrossRef] [PubMed]

46. Cheong, S.H.; Nydam, D.V.; Galvao, K.N.; Crosier, B.M.; Ricci, A.; Caixeta, L.S.; Sper, R.B.; Fraga, M.; Gilbert, R.O. Use of reagent test strips for diagnosis of endometritis in dairy cows. Theriogenology 2012, 77, 858-864. [CrossRef]

47. Couto, G.B.; Vaillancourt, D.H.; Lefebvre, R.C. Comparison of a leukocyte esterase test with endometrial cytology for diagnosis of subclinical endometritis in postpartum dairy cows. Theriogenology 2013, 79, 103-107. [CrossRef]

48. De Biase, D.; Costagliola, A.; Del Piero, F.; Di Palo, R.; Coronati, D.; Galiero, G.; Uberti, B.D.; Lucibelli, M.G.; Fabbiano, A.; Davoust, B.; et al. Coxiella burnetii in Infertile Dairy Cattle With Chronic Endometritis. Vet. Pathol. 2018, 55, 539-542. [CrossRef] [PubMed]

49. de Boer, M.; Buddle, B.M.; Heuer, C.; Hussein, H.; Zheng, T.; LeBlanc, S.J.; McDougall, S. Associations between intrauterine bacterial infection, reproductive tract inflammation, and reproductive performance in pasture-based dairy cows. Theriogenology 2015, 83, 1514-1524. [CrossRef] [PubMed]

50. de Sa, M.F.; Gonella-Diaza, A.M.; Sponchiado, M.; Mendanha, M.F.; Pugliesi, G.; Ramos, R.D.; Andrade, S.C.D.; Gasparin, G.; Coutinho, L.L.; Goissis, M.D.; et al. Impact of hormonal modulation at proestrus on ovarian responses and uterine gene expression of suckled anestrous beef cows. J. Anim. Sci. Biotechnol. 2017, 8, 79. [CrossRef]

51. Denis-Robichaud, J.; Dubuc, J. Determination of optimal diagnostic criteria for purulent vaginal discharge and cytological endometritis in dairy cows. J. Dairy Sci. 2015, 98, 6848-6855. [CrossRef] [PubMed]

52. Gabai, G.; De Luca, E.; Miotto, G.; Zin, G.; Stefani, A.; Da Dalt, L.; Barberio, A.; Celi, P. Relationship between Protein Oxidation Biomarkers and Uterine Health in Dairy Cows during the Postpartum Period. Antioxidants 2019, 8, 21. [CrossRef]

53. Kasimanickam, R.; Cornwell, J.M.; Nebel, R.L. Effect of presence of clinical and subclinical endometritis at the initiation of Presynch-Ovsynch program on the first service pregnancy in dairy cows. Anim. Reprod. Sci. 2006, 95, 214-223. [CrossRef] 
54. Katagiri, S.; Takahashi, Y. Potential relationship between normalization of endometrial epidermal growth factor profile and restoration of fertility in repeat breeder cows. Anim. Reprod. Sci. 2006, 95, 54-66. [CrossRef]

55. Machado, V.S.; Knauer, W.A.; Bicalho, M.L.S.; Oikonomou, G.; Gilbert, R.O.; Bicalho, R.C. A novel diagnostic technique to determine uterine health of Holstein cows at 35 days postpartum. J. Dairy Sci. 2012, 95, 1349-1357. [CrossRef]

56. Madoz, L.V.; Giuliodori, M.J.; Jaureguiberry, M.; Plöntzke, J.; Drillich, M.; Sota, R.L.d.l. The relationship between endometrial cytology during estrous cycle and cutoff points for the diagnosis of subclinical endometritis in grazing dairy cows. J. Dairy Sci. 2013, 96, 4333-4339. [CrossRef]

57. McDougall, S.; Hussein, H.; Aberdein, D.; Buckle, K.; Roche, J.; Burke, C.; Mitchell, M.; Meier, S. Relationships between cytology, bacteriology and vaginal discharge scores and reproductive performance in dairy cattle. Theriogenology 2011, 76, 229-240. [CrossRef]

58. Nehru, D.A.; Dhaliwal, G.S.; Jan, M.H.; Cheema, R.S.; Kumar, S. A non-invasive diagnostic test for subclinical endometritis in buffaloes. Indian J. Anim. Sci. 2019, 89, 140-144.

59. Pascottini, O.B.; Hostens, M.; Dini, P.; Van Eetvelde, M.; Vercauteren, P.; Opsomer, G. Prevalence of cytological endometritis and effect on pregnancy outcomes at the time of insemination in nulliparous dairy heifers. J. Dairy Sci. 2016, 99, 9051-9056. [CrossRef] [PubMed]

60. Pascottini, O.B.; Hostens, M.; Sys, P.; Vercauteren, P.; Opsomer, G. Cytological endometritis at artificial insemination in dairy cows: Prevalence and effect on pregnancy outcome. J. Dairy Sci. 2017, 100, 588-597. [CrossRef]

61. Prunner, I.; Pothmann, H.; Wagener, K.; Giuliodori, M.; Huber, J.; Ehling-Schulz, M.; Drillich, M. Dynamics of bacteriologic and cytologic changes in the uterus of postpartum dairy cows. Theriogenology 2014, 82, 1316-1322. [CrossRef]

62. Ricci, A.; Gallo, S.; Molinaro, F.; Dondo, A.; Zoppi, S.; Vincenti, L. Evaluation of subclinical endometritis and consequences on fertility in Piedmontese beef cows. Reprod. Domest. Anim. 2015, 50, 142-148. [CrossRef]

63. Salasel, B.; Mokhtari, A.; Taktaz, T. Prevalence, risk factors for and impact of subclinical endometritis in repeat breeder dairy cows. Theriogenology 2010, 74, 1271-1278. [CrossRef]

64. Santos, N.R.; Lamb, G.C.; Brown, D.R.; Gilbert, R.O. Postpartum endometrial cytology in beef cows. Theriogenology 2009, 71, 739-745. [CrossRef]

65. Scolari, S.C.; Pugliesi, G.; Strefezzi, R.D.; Andrade, S.C.D.; Coutinho, L.L.; Binelli, M. Dynamic remodeling of endometrial extracellular matrix regulates embryo receptivity in cattle. Reproduction 2017, 153, 49-61. [CrossRef]

66. Senosy, W.; Uchiza, M.; Tameoka, N.; Izaike, Y.; Osawa, T. Evaluation of Reproductive Tract Infection During Early Post-Partum Period and Its Relationship with Subsequent Reproductive Performance in High Milk Producing Dairy Cows. Reprod. Domest. Anim. 2012, 47, 203-207. [CrossRef]

67. Sens, A.; Heuwieser, W. Presence of Escherichia coli, Trueperella pyogenes, alpha-hemolytic streptococci, and coagulase-negative staphylococci and prevalence of subclinical endometritis. J. Dairy Sci. 2013, 96, 6347-6354. [CrossRef]

68. Van Schyndel, S.J.; Pascottini, O.B.; LeBlanc, S.J. Comparison of cow-side diagnostic techniques for subclinical endometritis in dairy cows. Theriogenology 2018, 120, 117-122. [CrossRef]

69. Werner, A.; Suthar, V.; Plöntzke, J.; Heuwieser, W. Relationship between bacteriological findings in the second and fourth weeks postpartum and uterine infection in dairy cows considering bacteriological results. J. Dairy Sci. 2012, 95, 7105-7114. [CrossRef]

70. Zaayer, D.; van der Horst, C.J. Non-fertility in cows: Treatment with PGF and investigation of uterine biopsies. Cytobios 1986, 45, 55-70.

71. Oliveira, B.M.; Arruda, R.P.; Thome, H.E.; Maturana Filho, M.; Oliveira, G.; Guimaraes, C.; Nichi, M.; Silva, L.A.; Celeghini, E.C. Fertility and uterine hemodynamic in cows after artificial insemination with semen assessed by fluorescent probes. Theriogenology 2014, 82, 767-772. [CrossRef]

72. Brook, D. Uterine cytology. In Equine Reproduction; Lea \& Febiger: Malvern, PA, USA, 1993; pp. $246-254$.

73. Kasimanickam, R.; Duffield, T.F.; Foster, R.A.; Gartley, C.J.; Leslie, K.E.; Walton, J.S.; Johnson, W.H. A comparison of the cytobrush and uterine lavage techniques to evaluate endometrial cytology in clinically normal postpartum dairy cows. Can. Vet. J. 2005, 46, 255-259.

74. Linton, J.K.; Sertich, P.L. The impact of low-volume uterine lavage on endometrial biopsy classification. Theriogenology 2016, 86, 1004-1007. [CrossRef]

75. Ball, B.A.; Shin, S.J.; Patten, V.H.; Lein, D.H.; Woods, G.L. Use of a low-volume uterine flush for microbiologic and cytologic examination of the mare's endometrium. Theriogenology 1988, 29, 1269-1283. [CrossRef]

76. Hannan, N.J.; Nie, G.; Rainzcuk, A.; Rombauts, L.J.; Salamonsen, L.A. Uterine lavage or aspirate: Which view of the intrauterine environment? Reprod. Sci. 2012, 19, 1125-1132. [CrossRef]

77. Koblischke, P.; Kindahl, H.; Budik, S.; Aurich, J.; Palm, F.; Walter, I.; Kolodziejek, J.; Nowotny, N.; Hoppen, H.O.; Aurich, C. Embryo transfer induces a subclinical endometritis in recipient mares which can be prevented by treatment with non-steroid anti-inflammatory drugs. Theriogenology 2008, 70, 1147-1158. [CrossRef]

78. Macmillan, K.; Loree, K.; Mapletoft, R.J.; Colazo, M.G. Short communication: Optimization of a timed artificial insemination program for reproductive management of heifers in Canadian dairy herds. J. Dairy Sci. 2017, 100, 4134-4138. [CrossRef]

79. Brinsko, S.P.; Varner, D.D.; Blanchard, T.L. The effect of uterine lavage performed four hours post insemination on pregnancy rate in mares. Theriogenology 1991, 35, 1111-1119. [CrossRef] 
80. Ribeiro, E.S.; Santos, J.E.; Thatcher, W.W. Role of lipids on elongation of the preimplantation conceptus in ruminants. Reproduction 2016, 152, R115-R126. [CrossRef] [PubMed]

81. Dorniak, P.; Bazer, F.; Spencer, T. Physiology and Endocrinology Symposium: Biological role of interferon tau in endometrial function and conceptus elongation. J. Anim. Sci. 2013, 91, 1627-1638. [CrossRef]

82. Meikle, A.; Sahlin, L.; Ferraris, A.; Masironi, B.; Blanc, J.E.; Rodríguez-Irazoqui, M.; Rodríguez-Piñón, M.; Kindahl, H.; Forsberg, M. Endometrial mRNA expression of oestrogen receptor alpha, progesterone receptor and insulin-like growth factor-I (IGF-I) throughout the bovine oestrous cycle. Anim. Reprod. Sci. 2001, 68, 45-56. [CrossRef]

83. Katagiri, S.; Moriyoshi, M.; Yanagawa, Y. Endometrial epidermal growth factor profile and its abnormalities in dairy cows. J. Reprod. Dev. 2016, 62, 465-470. [CrossRef] 